\title{
Principles of Neutrality and Impartiality of Humanitarian Action in the Aftermath of the 2011 Libyan Conflict
}

\author{
Kubo Mačák \\ University of Exeter
}

SUBMITTED FOR PUBLICATION IN:

Andrej Zwitter et al (eds), Humanitarian Action: Global, Regional and Domestic Legal Responses, Cambridge University Press, 2014 (forthcoming) 


\title{
Principles of Neutrality and Impartiality of Humanitarian Action in the Aftermath of the 2011 Libyan Conflict
}

\begin{abstract}
Kubo Mačák ${ }^{1}$

\section{Introduction}

Have the principles of neutrality and impartiality of humanitarian action become a myth, a dead concept emptied of its contents due to the reality of modern asymmetrical armed conflicts? This chapter considers the events of the Libyan civil war of 2011 against the legal backdrop of international humanitarian law (IHL) to argue that although these two principles have been placed under severe strain in Libya, any reports of their death would nonetheless be greatly exaggerated. Although the trend of their weakening that has been observed in the wars in Iraq and Afghanistan has in some ways continued, they still constitute, in law and in practice, the guiding principles of humanitarian action.

Neutrality and impartiality of humanitarian action ${ }^{2}$ are not strict legal obligations incumbent upon every humanitarian agent acting in situations of extreme human need and suffering. They are, however, generally considered to be 'fundamental principles' or 'pillars' of humanitarian action. ${ }^{3}$ They have acquired legal relevance due to their repeated affirmation in numerous international legal documents of both binding and non-binding nature. Actors that have thus committed themselves to adhere to these principles include various States, ${ }^{4}$ the United Nations (both through its General Assembly ${ }^{5}$ and the Security Council ${ }^{6}$ ), the European Union, ${ }^{7}$ the
\end{abstract}

\footnotetext{
${ }^{1}$ Lecturer in Law at the University of Exeter and DPhil Candidate in International Law at the University of Oxford (Somerville College). E-mail: k.macak@exeter.ac.uk. I would like to thank Ana Beduschi, Max Forte, Slávka Mačáková, Mona Sadek, Mike Sanderson, and Noam Zamir for their time and advice which they have generously shared with me during the preparation of this paper. All internet resources were last accessed on 1 April 2013.

${ }^{2}$ In this contribution, 'humanitarian action' is understood narrowly as action aimed to protect the victims of armed conflicts by providing them with food, water, sanitation, shelter, health services and other forms of emergency assistance as well as by ensuring that violations are monitored and addressed, but excluding measures whose implementation carries a political charge such as post-conflict development and social work.

${ }^{3}$ See, eg, Kenneth Anderson, "Humanitarian Inviolability in Crisis: The Meaning of Impartiality and Neutrality for U.N. and NGO Agencies Following the 2003-2004 Afghanistan and Iraq Conflicts", Harvard Human Rights Journal 17 (2004), p. 41.

${ }^{4}$ See, eg, Swiss Federal Department of Foreign Affairs, "Humanitarian Access in Situations of Armed Conflict: Field Manual_Version 1.0” (2011), http://www.cdint.org/documents/PAIV_111118_Humanitarian_Access_Field Manual_mit_Inhalt.pdf, section 3.2; UK Department for International Development, "Saving lives, preventing suffering and building resilience: The UK Government's Humanitarian Policy" (2011), http://www.dfid.gov.uk/Documents/publications1/1/The UK Government's Humanitarian Policy September 2011 Final.pdf, p. 6.

${ }^{5}$ UN GA Res. 46/182 (1991), Annex, para. 2. These principles were frequently reaffirmed by the General Assembly in the following years. See, eg, UN GA Res. 51/194 (1996), preambular para. 12; UN GA Res. 58/114 (2003), preambular para. 4; UN GA Res. 60/124 (2005), preambular para. 4; UN GA Res. 61/134 (2006), preambular para. 4; UN GA Res. 62/94 (2007), preambular para. 3; UN GA Res. 63/139 (2008), preambular para. 3; UN GA Res. 66/119 (2011), preambular para. 3.
} 
International Committee of the Red Cross (ICRC), ${ }^{8}$ and a plethora of humanitarian NGOs. ${ }^{9}$ As 'fundamental principles of the Red Cross', they have been given further recognition in the Geneva Conventions and their Additional Protocol I. ${ }^{10}$

Due to a lack of a generally accepted definition, the content of these principles as understood by the relevant actors may slightly differ. As used in general language, the two terms might even appear synonymous. ${ }^{11}$ However, for the purposes of this contribution, we may attempt to delimit their core as follows. The principle of neutrality requires the humanitarian actors to remain ideologically free and to not favour any of the conflict parties. ${ }^{12}$ The principle of impartiality requires these actors to provide aid only on the basis of, and in proportion to, the need of the victims. ${ }^{13}$ The two principles are thus complementary ${ }^{14}$ and are aimed to ensure the distribution of assistance irrespective of the prevailing political or military balance or perceived military necessity ${ }^{15}$ and, correspondingly, to protect the safety of humanitarian actors by maintaining their perception as being concerned solely with the needs of the victims. ${ }^{16}$

The importance of humanitarian principles thus cannot be overstated. However, in recent discourse, commentators have mourned their demise, arguing that they are no longer followed by the relevant State and non-State actors. For example, Kurt Mills complained in 2005:

The traditional ideals of neutrality, impartiality, and independence have become myth. Rather than being at the margins of conflict, humanitarianism is now embedded within contemporary conflict. States use humanitarian norms and actors for their own ends. ${ }^{17}$

${ }^{6}$ UN SC PrSt 1997/34 (19 June 1997), p. 2; UN SC Res. 1296 (2000), preambular para. 11; UN SC PrSt $2004 / 46$ (14 December 2004), p. 2; UN SC Res. 1674 (2006), para. 21.

7 Treaty on the Functioning of the European Union, Art. 214(2) (hereinafter 'TFEU').

$8 X^{\text {th }}$ International Conference of the Red Cross, "Proclamation of the Fundamental Principles of the Red Cross" 56 IRRC (1965), pp. 573-4.

9 See, eg, MSF, "MSF Charter" (3 January 2011), http://www.msf.org/msf/articles/2011/03/the-medecins-sansfrontieres-charter.cfm; IOM, Res. 1243 (CI) "IOM Migration Crisis Operational Framework" (27 November 2012); International Rescue Committee, “Organization Report" (June 2011), http://rootcause.org/documents/DRIRC.pdf.

10 Geneva Convention I, Art. 44(2); Geneva Convention IV, Art. 63(1)(a); Additional Protocol I, Art. 81(2)-(3) (hereinafter 'GC' and 'AP', respectively).

11 See, eg, 'Neutral', Thesaurus.com, http://thesaurus.com/browse/neutral ('Definition: impartial, noncommital') (emphasis added).

12 Marion Harroff-Tavel, "Neutrality and Impartiality-The Importance of These Principles for the International Red Cross and Red Crescent Movement and the Difficulties Involved in Applying Them," IRRC 873 (1989), p. 537; Anderson, "Humanitarian Inviolability", p. 56; EU, Joint Statement by the Council and the Representatives of the Governments of the Member States meeting within the Council, the European Parliament and the European Commission: The European Consensus on Humanitarian Aid, OJ 2008 C 25/1, C 25/2, para. 12 (hereinafter 'The European Consensus on Humanitarian Aid').

${ }^{13}$ Harroff-Tavel, "Neutrality and Impartiality", p. 538; Anderson, "Humanitarian Inviolability", p. 56; The European Consensus on Humanitarian Aid, para. 13.

${ }_{14}$ Due to their complementarity, this contribution generally considers the two principles together, except where expressly stated otherwise.

15 Anderson, "Humanitarian Inviolability", p. 56.

16 Alice Gadler, "Armed Forces as Carrying Both the Stick and the Carrot? Humanitarian Aid in U.S. Counterinsurgency Operations in Afghanistan and Iraq," Goettingen Journal of International Law 3-1 (2011), p. 227.

17 Kurt Mills, "Neo-Humanitarianism: The Role of International Humanitarian Norms and Organizations in Contemporary Conflict" Global Governance 11-2 (2005), p. 161. 
The two defining large-scale wars of the first decade of the twenty-first century, Iraq and Afghanistan, have occasioned a wave of criticism decrying the abandonment of impartiality and neutrality in those conflicts. Critics have highlighted as problematic the instrumentalisation of humanitarian action by Western militaries, ${ }^{18}$ conflation of humanitarian and development roles of humanitarian agents, ${ }^{19}$ and the general blurring of lines between political, military, and humanitarian agendas. ${ }^{20}$

This is the background of the analysis provided in this chapter, which is divided into three main parts. Part I provides the legal framework applicable to the provision of humanitarian action during the Libyan conflict from the perspective of IHL. Part II analyses how principles of neutrality and impartiality of humanitarian action have been respected by the quantitative and qualitative nature of aid provided in Libya by external actors. Part III analyses to what extent the conflict posed a challenge to neutrality and impartiality with respect to agents of humanitarian action, contrasting the different problems faced by humanitarian agencies on the one hand and multi-purpose actors on the other. The conclusion draws lessons to be learned from the analysis presented and supports on its basis the central claim of this chapter that the two principles, even if badly battered during the war, are still alive and kicking.

\section{Legal framework}

Norms of IHL apply only in situations of armed conflict. In order to analyse humanitarian action provided in the scope of the Libyan war of 2011 through the lens of IHL, we thus first need to determine which phases of violence since its outbreak in February of that year met the legal criteria for one of the two main types of armed conflict. ${ }^{21}$ It is argued here that the situation in Libya became a non-international armed conflict (NIAC) towards the end of February. The NIAC between the government and the rebel forces was then complemented by an international armed conflict (IAC) between the State of Libya and the foreign intervening forces. It is as of now factually unclear whether the growing collusion between the intervening States and the Benghazi-based insurgents surpassed the level required to transform the latter into another party of the IAC. In any event, norms of NIAC and IAC both applied to the events in Libya at various times. ${ }^{22}$

The NIAC in Libya commenced when the fighting reached a level of intensity and when the rebels achieved a level of organisation required by law and international jurisprudence. ${ }^{23}$ The intensity requirement was met when non-violent protests in several Libyan cities grew into armed confrontations in late February 2011, with heavy armed force deployed by the government ${ }^{24}$ and

\footnotetext{
18 Vincent Bernard, "Editorial: The Future of Humanitarian Action," IRRC 884 (2011), p. 892; Fiona Terry, "The International Committee of the Red Cross in Afghanistan: Reasserting the Neutrality of Humanitarian Action," IRRC 881 (2011), p. 175; Mills, “Neo-Humanitarianism”, pp. 177-9.

19 Antonio Donini, "Between a Rock and a Hard Place: Integration or Independence of Humanitarian Action?" IRRC 881, p. 152; Anderson, "Humanitarian Inviolability”, pp. 42-3.

${ }^{20}$ Claudia McGoldrick, "The Future of Humanitarian Action: An ICRC Perspective," IRRC 884 (2011), p. 966; Anderson, "Humanitarian Inviolability", p. 64; Gadler, "Armed Forces”, p. 231.

21 On classification of armed conflicts see generally Dapo Akande, "Classification of Armed Conflicts: Relevant Legal Concepts" in: Elizabeth Wilmshurst (ed.), International Law and the Classification of Conflicts, (OUP: Oxford, 2012), pp. 32-79.

${ }^{22}$ The analysis in this section is based on a recent article on the qualification of the Libyan conflict, co-written by the present author. See Kubo Mačák and Noam Zamir, "The Applicability of International Humanitarian Law to the Conflict in Libya," International Community Law Review 14-4 (2012), p. 403.

23 Prosecutor v. Tadic (Jurisdiction Appeal) IT-94-1-AR72 (2 October 1995), para. 70 ("[A non-international] armed conflict exists whenever there is [...] protracted armed violence between governmental authorities and organized armed groups or between such groups within a State') (emphases added).

24 See, eg, BBC, "Libya Unrest: Scores Killed in Benghazi 'Massacre,", 20 February 2011, http://www.bbc.co.uk/news/world-africa-12517327; Haaretz, "Report: Libya Air Force Bombs Protesters Heading
} 
with the insurgents forcefully taking over garrisons and towns all across Libya. ${ }^{25}$ The organisation requirement was met when the resistance fighters formed geographically rooted militias ('kataeb') led by military commanders and capable of enforcing compliance with IHL within their ranks. ${ }^{26}$ In addition, opposition armed forces established themselves in the eastern city of Benghazi and by late February, they were controlling several other cities including Shahat, Tobruk, and Misrata. ${ }^{27}$ The key requirement of partial territorial control, triggering the applicability of Additional Protocol II, was thus also met by that point of time in Libya. ${ }^{28}$

According to the ICTY's interpretation of the terms of Common Article 2 to the Geneva Conventions, an IAC begins when there is 'a resort to armed force between States'. ${ }^{29}$ In the Libyan conflict, this situation materially came about on 19 March when the US, the UK, and France used its naval and airborne forces to attack targets in Libya. ${ }^{30}$ The fact that NATO assumed formal and operational control of all international forces on 31 March did not change the qualification of the conflict; it only made NATO a party to the conflict, equally bound by the rules of IHL. ${ }^{31}$ For now, it remains an open question whether this parallel IAC merged at some point with the NIAC described in the previous paragraph. A plausible argument to that effect could be made if it were proven that the rebels forfeited their operational autonomy and accepted a degree of control by NATO. ${ }^{32}$ However, the reports of the establishment in Benghazi of a 'joint operations centre', allegedly tasked with the co-ordination of NATO and rebels' operations against Gaddafi, have not been authoritatively confirmed to this day. ${ }^{33}$

On this basis, this contribution considers the situation in Libya as featuring two parallel conflicts, a NIAC between the government and the rebels, and an IAC between the government

For Army Base," 21 February 2011, www.haaretz.com/news/world/report-libya-air-force-bombs-protestersheading-for-army-base-1.344775; STRATFOR, "Unrest and the Libyan Military," 21 February 2011, www.stratfor.com/analysis/20110220-unrest-libyan-military.

25 Arab Organization for Human Rights, "Report of the Independent Civil Society Fact-Finding Mission to Libya" (January 2012), para. 48; UN Human Rights Council, "Report of the International Commission of Inquiry to Investigate All Alleged Violations of International Human Rights Law in the Libyan Arab Jamahiriya," UN Doc. A/HRC/17/44 (12 January 2012), paras. 28, 55.

26 UN Human Rights Council, "Report of the International Commission of Inquiry on Libya," UN Doc. A/HRC/19/68 (2 March 2012), Annex I, paras. 61-63 (hereinafter 'International Commission of Inquiry March 2012 Report').

27 Alexander Dziadosz, "Benghazi, Cradle of Revolt, Condemns Gaddafi," The Star, 23 February 2011, http://thestar.com.my/news/story.asp?file $=/ 2011 / 2 / 24 /$ worldupdates $/ 2011-02$ -

23T222628Z_01_NOOTR_RTRMDNC_0_-550982-4\&sec=Worldupdates (confirming the establishment of control over Benghazi); International Commission of Inquiry March 2012 Report, para. 55 (regarding Shahat, Tobruk, and Misrata).

28 AP II, Art. 1(1).

29 Tadic Jurisdiction Appeal, para. 70; see also Jean Pictet (ed.), Geneva Convention relative to the Protection of Civilian Persons in Time of War: Commentary, (ICRC: Geneva, 1958), p. 20.

30 See, eg, The Guardian, “Allied Strikes Sweep Libya as West Intervenes in Conflict," 20 March 2011, www.guardian.co.uk/world/2011/mar/19/libya-air-strikes-gaddafi-france; BBC News, "Libya: US, UK and France Attack Gaddafi Forces,” 20 March 2011, http://www.bbc.co.uk/news/world-africa-12796972.

${ }^{31}$ For detailed analysis, see Mačák and Zamir, "The Applicability”, pp. 416-8.

32 The co-operation between NATO and the rebels would thus meet the 'overall control' test propounded by the jurisprudence of the ICTY, which requires (1) the provision of financial and training assistance, military equipment and/or operational support to the non-State party and (2) the participation in the organisation, coordination or planning of military operations by the intervening State. See Prosecutor $v$. Tadic (Appeal Judgement) IT-94-1-A (15 July 1999), paras. 131, 145, 162.

33 See Bruno Waterfield, "Libya: British Military Advisers Set up 'Joint Operations Centre' in Benghazi," The Telegraph, 18 May 2011, www.telegraph.co.uk/news/worldnews/africaandindianocean/libya/8521977/Libya-Britishmilitary-advisers-set-up-joint-operations-centre-in-Benghazi.html (confirmation by the UK); Maher Chmaytelli and Peter S. Green, "Libya Rebels, NATO Don’t Have Joint Operations, Official Says,” Bloomberg, 16 April 2011, http://www.bloomberg.com/news/2011-04-16/libya-rebels-nato-don-t-have-joint-operations-official-says.html (confirmation by the rebels and denial by NATO). 
and the intervening forces. The IHL obligations of this triangle of conflict parties, including the duties pertaining to the provision of humanitarian assistance, thus differed depending on the conflict pair that formed the factual background for the relevant events. The main difference relevant for our purposes, besides the generally more robust and detailed regulation of IACs, is the requirement of State consent to humanitarian assistance provided in its territory in the scope of a NIAC. ${ }^{34}$

\section{Nature of humanitarian action}

The Libyan conflict affected virtually the entire territory of the State of Libya. Civilians living in almost all areas of the country were exposed to the dangers of armed violence and to shortages of basic supplies and services including, among many other things, food, water, fuel, and medical attention. Both sides of the conflict in official statements repeatedly acknowledged the dire nature of the situation and requested outside humanitarian assistance. For example, Lynn Pascoe, the UN Under-Secretary-General for Political Affairs, reported in May 2011 to the UN Security Council that the Libyan government demanded from the UN to arrange for the resumption of the supply of fuel to 'ensure the continuation of basic services' and that the rebel-led National Transitional Council complained that it had 'only 40 per cent of the funds needed to cover its budget for April and May. ${ }^{35}$ Both sides continued to report severe shortages and requested later that the Libyan State assets that had been frozen under the terms of the UN Security Council resolution $1973(2011)^{36}$ be released and used 'to meet humanitarian needs'.

Although it is beyond the scope of this contribution to provide a definitive assessment of the humanitarian aid provided to the individual belligerents in Libya, a number of indications cast a shadow on the purported neutrality and impartiality of the assistance provided in two different but intertwined ways. These relate to the qualitative and quantitative nature of aid provided during the conflict.

\section{a. Quantitative assessment}

The first problematic quantitative aspect is that the majority of aid designated for Libya originated in those countries that participated in the multinational military intervention that ended up supporting the insurgents. Out of ten European countries that contributed the most, ${ }^{38}$ only two did not take part in the NATO-led military operations: Germany and Finland, ${ }^{39}$ of which the latter has long been committed to a policy of military neutrality and non-alignment. ${ }^{40}$ It could plausibly be objected that countries that intervened militarily only happened to be those that ordinarily provide humanitarian aid, in line with the general trend according to which it is

\footnotetext{
34 See subsection III.A below.

35 UN Doc. S/PV.6541 (31 May 2011), p. 2.

${ }^{36}$ See text to note 113 below.

${ }^{37}$ UN Doc. S/PV.6595 (28 July 2011), p. 2.

38 The Guardian, "Humanitarian Aid in Libya: How Much Has Each Country Donated?" 22 August 2011, http://www.guardian.co.uk/news/datablog/2011/aug/22/libya-humanitarian-aid-by-country.

39 The Guardian, "Nato Operations in Libya: Data Journalism Breaks Down Which Country Does What" 22 May 2011, http://www.guardian.co.uk/news/datablog/2011/may/22/nato-libya-data-journalism-operations-country.

40 Marco Wyss, "Military Transformation in Europe's Neutral and Non-Neutral Allies," The RUSI Journal 156-2 (2011), pp. 46-7. The Finnish foreign minister expressed the support of his country for the UN Security Council Resolution 1973 (2011) but stated that this support 'would take the form of humanitarian aid, including help with the evacuation of refugees'. Hans Lödén, "Reaching a Vanishing Point? Reflections on the Future of Neutrality Norms in Sweden and Finland," Cooperation and Conflict 47-2 (2012), pp. 275-6.
} 
the global West that provides the majority of aid. ${ }^{41}$ This objection, however, only brings us to the second problematic aspect, namely that the rebels and areas under their control profited disproportionately more from international aid than the government and government-controlled areas.

In large part, this disproportion arose from the actions of an informal 'contact group' established in late March $2011^{42}$ and comprised of about forty nations that made no secret of their dislike of Gaddafi. ${ }^{43}$ At its meeting in June 2011, the members of the contact group pledged more than $\$ 1$ bn in support for the Libyan opposition. ${ }^{44}$ In addition, at the behest of this group, ${ }^{45}$ the rebels were allowed to benefit from about $\$ 1.5 \mathrm{bn}$ of Libyan assets that were unfrozen by the Sanctions Committee of the UN Security Council in August 2011. ${ }^{46}$

It also appears from early reports from the conflict that virtually all outside assistance was intended for the eastern, rebel-controlled part of Libya ${ }^{47}$ and that as the conflict was underway, areas controlled by the government suffered from worse shortages than their better supplied rebel-held counterparts. ${ }^{48}$ These facts in their combination therefore indicate that the aid designated to alleviate the hardships of the Libyan conflict originated disproportionately in the countries intervening in support of one side of the conflict and that it benefited disproportionately persons associated with that side.

\section{b. Qualitative assessment}

Qualitatively, some of the aid disbursed to the rebels, but not to the government forces, exceeded what can legitimately be considered humanitarian assistance and constituted assistance of the kind that could significantly affect the insurgents' war effort. According to the ICJ's ruling in Nicaragua, provision of assistance going beyond 'food, clothing, medicine and other humanitarian assistance', and especially of 'weapons, weapons systems, ammunition, or other equipment, vehicles, or material which can be used to inflict serious bodily harm or death' cannot be considered as humanitarian aid. ${ }^{49}$ Their provision to the rebels would thus amount to unlawful interference with the internal affairs of Libya and to a violation of the principles of impartiality and neutrality.

But perhaps such assistance could be justified on the basis of the Security Council authorisation contained in Resolution 1973. The arguments that the international coalition overstepped the mandate to protect civilians and civilian-populated areas given to it by the

\footnotetext{
${ }^{41}$ Cf. Bernard, "Editorial", p. 891 (noting that the headquarters of all main humanitarian agencies are in the Western world). 
Security Council in order to effectuate regime change in Libya will be discussed below. ${ }^{50}$ However, is it correct to argue that the enabling resolution, understood as limited to the civilianprotection aim, allowed for the transfer of military supplies in furtherance of this mandate? If such aid was permitted by the terms of the resolution, this permission would prevail over the requirements arising from the principles of neutrality and impartiality by virtue of Article 103 of the UN Charter. ${ }^{51}$

It should be recalled that the predecessor Resolution 1970 expressly established an arms embargo in its operative paragraph 9. Under its terms, any 'direct or indirect supply, sale or transfer' or arms and related materiel to Libya was prohibited, irrespective of who (if anyone) would benefit from such a transaction. ${ }^{52}$ It is true that Resolution 1973 authorised UN Member States to take all necessary measures 'notwithstanding paragraph 9 of resolution 1970 (2011)'. ${ }^{53}$ However, as a resolution permitting the use of force in international relations, Resolution 1973 represents an exception from the general prohibition on the use of force ${ }^{54}$ and thus its terms should be interpreted restrictively, in line with the general principle of law that exceptions from a rule are to be construed narrowly. ${ }^{55}$ The most likely motive for the inclusion of the quoted phrase in the newer resolution was to allow the coalition to transport their own military materiel to Libya. ${ }^{56}$ Moreover, the resolution does allow the implementing States to act either 'nationally' or 'through regional organizations or arrangements', but it does not, notably, allow for action in collusion with other (sub-State) entities. ${ }^{57}$ The narrow interpretation advocated here thus precludes the transfer of military equipment to one of the parties even under the terms of Resolution $1973 .^{58}$ It is also in line with the unequivocal statement of the NATO Secretary General from March 2011 that the resolution did not allow the arming of the rebels, although, admittedly, his view was not shared by all NATO member States. ${ }^{59}$

There have been a number of reports that outside States provided military assistance to the insurgents in Libya. Few countries expressly admitted doing so. Qatar did in April 2011, seemingly on the basis of its earlier recognition of the National Transitional Council (NTC) as the legitimate government of Libya. ${ }^{60}$ It was rightly pointed out, however, that prior to

\footnotetext{
50 See section III.B.1 below.

${ }^{51}$ UN Charter, Art. 103; see also Lockerbie case (Libya v. United Kingdom) (Request for the Indication of Provisional Measures), ICJ Reports 1992, p. 15, para. 39 (obligations imposed by the Security Council acting under Chapter VII of the UN Charter trump any conflicting international law obligations).

52 UN SC Res. 1970 (2011), para. 9.

53 UN SC Res. 1973 (2011), para. 4.

${ }^{54}$ See, eg, Malcolm N. Shaw, International Law, 6th ed. (CUP: Cambridge, 2008), pp. 1123-4.

55 Cf. Roman law principles of 'Exceptiones sunt strictae interpretationis' or 'Singularia non sunt extendenda'. See also Dan Sarooshi, United Nations and the Development of Collective Security: the Delegation by the UN Security Council of its Chapter VII Powers (OUP: Oxford, 1999), pp. 44-6 (the requirement of narrow construction of powers delegated by the Security Council is a consequence of the application of the delegatus non potest delegare doctrine to the Council); Ben Saul, "The Legality of the Use of Force against Iraq in 2003: Did the Coalition Defend or Defy the United Nations," UCLAJ. Int'l L. \& Foreign Aff 8 (2003), p. 315 (resolutions authorising the use of force must be construed narrowly to protect the Council's control over its own process).

${ }^{56}$ C Pippan, “The 2011 Libyan Uprising, Foreign Military Intervention, and International Law," Juridikum: Zeitschrift für Kritik-Recht-Gesellschaft 2 (2011), p. 167.

${ }^{57}$ Cf. UN SC Res. 1973 (2011), paras. 4 and 8.

58 Contra Dapo Akande, "Does SC Resolution 1973 Permit Coalition Military Support for the Libyan Rebels?," EJIL: Talk!, 31 March 2011, http://www.ejiltalk.org/does-sc-resolution-1973-permit-coalition-military-support-forthe-libyan-rebels/; Pippan, "The 2011 Libyan Uprising”, pp. 167-8.

59 Sky News, "Confusion Reigns Over Arming Libyan Rebels," 31 March 2011, http://news.sky.com/story/844958/confusion-reigns-over-arming-libyan-rebels.

60 The New York Times, "Libyan Rebels Say They're Being Sent Weapons," 16 April 2011, http://www.nytimes.com/2011/04/17/world/africa/17libya.html.
} 
consolidation of control over territory by the rebels, such recognition would have been premature and thus unlawful under international law. ${ }^{61}$

France acknowledged its military aid and attempted to justify it under the humanitarian rationale of protecting the civilians from the government troops. ${ }^{62}$ Once the weapons are distributed, however, the donor country has, even if genuine in its aims, very little leverage over how they would eventually be used. What is more, according to journalistic reports and counter to the official proclamations, France has at least contemplated that French arms would be used by the rebels in their efforts to topple the regime in power. ${ }^{63}$

Other countries may have been providing arms and military training to the rebels more covertly. Even prior to the military intervention, the US, UK, and France were reported to have sent several hundred 'defence advisors' to train and support the insurgent forces in eastern Libya. $^{64}$ Additional covert deployments of special forces by Egypt, France, Italy, Qatar, the UAE, and the UK were reported during and after the conflict, usually accompanied by denials from the authorities. ${ }^{65}$ Finally, the rebels themselves confirmed having received military assistance from countries 'that supported their uprising', without specifying the exact sources of that support. ${ }^{66}$

It will be a task for historians and perhaps criminal investigators to confirm or deny authoritatively these reports of military assistance to the rebels. For the purposes of this contribution, it is sufficient to say that to the extent that aid to the rebels exceeded the range of permissible humanitarian assistance outlined in Nicaragua, it could not be considered justified under general international law or under the terms of Resolution 1973. In addition, as its provision was not mirrored in principle nor in extent by any commensurate aid provided to the governmental side, it cannot be seen as consistent with the principles of neutrality and impartiality, either.

\section{Agents of humanitarian action}

The conflict posed a further challenge to impartiality and neutrality of humanitarian action with respect to agents of humanitarian action. The two principal types of agents active in Libya were humanitarian agencies, with the ICRC at the forefront, and multi-purpose actors, such as outside States and especially international organisations, featuring prominently the UN, NATO, and the EU. Each of these two types faced somewhat different difficulties relevant to our scrutiny.

\section{a. Humanitarian agencies}

First of all, humanitarian agencies struggled primarily for equal access to the conflict victims. This section describes some of the problems of access during the conflict and places them within the framework of IHL. The discussion is unavoidably sketchy. On the one hand, the present analysis can correct some of the earlier generalisations such as that the ICRC was able to conduct

\footnotetext{
61 Stefan Talmon, "Recognition of the Libyan National Transitional Council," ASIL Insight, 16 June 2011, http://www.asil.org/insights110616.cfm.

62 France 24, "French Military Air-Dropped Arms to Libya Rebels," 29 June 2011, http://www.france24.com/en/20110629-french-military-confirms-airdropping-arms-libya-kadhafi-rebel\#. ${ }^{63}$ Ibid.

64 Pakistan Observer, "US, UK, French Forces Land in Libya," 26 February 2011, http://pakobserver.net/detailnews.asp?id=78009.

65 Paul D. Williams and Alex J. Bellamy, "Principles, Politics, and Prudence: Libya, the Responsibility to Protect, and the Use of Military Force," Global Governance 18 (2012), p. 291; Al Jazeera, "Libyan Rebels 'Receive Foreign Training,", 3 April 2011, http://www.aljazeera.com/news/africa/2011/04/201142172443133798.html.

66 The New York Times, "Libyan Rebels Say They're Being Sent Weapons," 16 April 2011, http://www.nytimes.com/2011/04/17/world/africa/17libya.html.
} 
its operations for the whole duration of air operations in the entire territory of Libya; ${ }^{67}$ in fact, the ICRC itself complained several times of difficulties of access ${ }^{68}$ On the other hand, the text has no ambition to paint an exhaustive picture of the humanitarian situation in Libya and examples chosen may be representative but due to the scope of this chapter have to remain anecdotal.

Unquestionably, the primary responsibility for the provision of humanitarian aid to the victims of wars lies with the territorial State. ${ }^{69}$ This is simply a reflection of the State's sovereignty which entails the responsibility for those living within its territory. ${ }^{70}$ In the territory in which the State has lost control to a non-State armed group, such as the NTC-led rebels in the Libyan conflict, this primary responsibility is complemented by a corresponding duty that arises for the non-State actor in question. This can be inferred from 'the dependence of the population on the humanitarian aid offered to it and ... the principles of humanity and inviolability binding on all parties'. ${ }^{71}$ In the Libyan context, the responsibility of both conflict parties to ensure the protection of civilians was underscored by Resolution $1973 .^{72}$ In any event, practical impossibility, difficulty or even unwillingness may prevent the conflict parties from fulfilling their primary duties towards the civilian population. In that case, the subsidiary role of relief societies, both domestic and foreign, comes to the fore. ${ }^{73}$

Although the conflict parties are prohibited from using starvation of civilians, broadly understood, ${ }^{74}$ as a method of combat, ${ }^{75}$ whether or not they are obliged to enable free passage of all humanitarian assistance to all civilians depends on the conflict qualification. In IACs, conflict parties must only grant free passage to medications intended for all civilians, whereas other forms of humanitarian assistance such as foodstuffs and clothing are to be obligatorily granted passage only to specified vulnerable groups of children under fifteen, expectant mothers, and maternity cases. ${ }^{76}$ All other relief action is 'subject to the agreement of the Parties concerned' in such actions, which naturally includes the belligerent parties. ${ }^{77}$ It is debated whether, if the aid offered meets the requisite conditions, ${ }^{78}$ the agreement may be withheld only if the aid amounted to a threat to the sovereignty of the target $\operatorname{State}^{79}$ or for any reason, as long as it is not arbitrary

67 Bruno Pommier, "The Use of Force to Protect Civilians and Humanitarian Action: The Case of Libya and Beyond," IRRC 884 (2011), p. 1081.

68 See, eg, ICRC, "Libya: ICRC Makes Urgent Call for Access to Wounded," 24 March 2011, http://www.icrc.org/eng/resources/documents/update/2011/libya-update-2011-03-24.htm (with respect to most areas affected by conflict in March); ICRC, "Libya: First Access to the Remote Area of Sabha," 3 June 2011, http://www.icrc.org/eng/resources/documents/update/2011/libya-update-2011-06-03.htm (with respect to the southern city of Sabha, where the ICRC got only in June); ICRC, "Libya: Safe Access Needed to Sirte and Bani Walid," 23 September 2011, http://www.icrc.org/eng/resources/documents/news-release/2011/libya-news-201109-23.htm (with regard to Sirte and Bani Walid in September).

${ }^{69}$ Yves Sandoz, Christophe Swinarski, and Bruno Zimmermann, eds., Commentary on the Additional Protocols of 8 June 1977 to the Geneva Conventions of 12 August 1949 (ICRC: Geneva, 1987), p. 1477, para. 4871 (hereinafter 'APs Commentary').

70 See, inter alia, UN GA Res. 46/182, Annex, para. 4.

${ }^{71}$ Ruth Abril Stoffels, "Legal Regulation of Humanitarian Assistance in Armed Conflict: Achievements and Gaps," IRRC 855 (2004), p. 520.

72 UN SC Res. 1973 (2011), preambular para. 4.

73 GC IV, Art. 23; AP I, Art. 70(1); GCs, Common Art. 3; AP II, Art. 18.

74 The prohibition does not only cover food, but also 'objects indispensable to the survival of the civilian population', including agricultural areas, drinking water installations, and irrigation works.

75 AP I, Art. 54; AP II, Art. 14.

${ }^{76}$ GC IV, Art. 23(1).

77 AP I, Art. 70(1);

78 AP I, Art. 70(1) (the civilian population is not adequately provided with fundamental supplies and the aid is 'humanitarian and impartial in character and conducted without any adverse distinction').

${ }^{79}$ APs Commentary, p. 819, para. 2805 (basing this interpretation on the travaux préparatoires of AP I). 
or capricious. ${ }^{80}$ In contrast, in NIACs, any and all relief action is always subjected to the consent of the territorial State. ${ }^{81}$ Interestingly, there is no corresponding written legal requirement of consent given by the non-State party in control of a part of the territory, although in practice, its consent is clearly indispensable, as well. ${ }^{82}$ In any event, by demanding unconditionally that 'the Libyan authorities' ensure the rapid and unimpeded passage of humanitarian assistance, ${ }^{83}$ the Security Council has significantly weakened the possibility of the conflict parties to claim a right to deny their consent to offers of relief action.

Perhaps at least partially aware of these considerations, neither of the conflict parties attempted to justify any significant instance of prevention of access by legal arguments going to the necessity vel non of consent or agreement given by such party. It can thus be assumed that neither the government nor the rebels were aware of any justifiable reason for such denials and these measures should accordingly be considered as prima facie indications of violations of the rules on humanitarian access.

It should not be denied that relief action may be prevented by objectively existing securityrelated constraints, especially while hostilities are ongoing. Humanitarian agencies reported the existence of such situations on numerous occasions. For example, the NGO Médecins Sans Frontières (MSF) complained that insecurity made it impossible to bring humanitarian aid to Tripoli in February 2011 ${ }^{84}$ and Misrata and Ras Lanuf in March 2011. ${ }^{85}$ Provided that these conditions are not deliberately brought upon in order to hamper the provision of aid, they do not result in accountability under IHL and must be accepted as an unfortunate fact of war. ${ }^{86}$

However, certain incidents left no doubt that the parties did not fully respect their access obligations. We will look at three situations, broadly speaking, in more detail: the beginning of the conflict in February and March, the siege of Misrata by Gaddafi's forces between March and May, and the siege of Sirte by the NTC in September and October.

First, in the first phase of the conflict prior to the international intervention, the Libyan government put on a resolute face towards mounting international pressure, including calls for enabling humanitarian access. It refused to permit the humanitarian convoys to enter those cities, such as Misrata and Ajdabiya, which it was attempting to recapture. ${ }^{87}$ Moreover, according to media reports and NGO statements, Gaddafi's forces were preventing medical teams from

\footnotetext{
80 Yoram Dinstein, The Conduct of Hostilities under the Law of International Armed Conflict, 2nd ed. (CUP: New York, 2010), p. 227.

81 AP II, Art. 18(2).

82 Michael Bothe, "Relief Actions," in: Rudolf Bernhardt (ed.), Encyclopedia of Public International Law, vol. 4 (Elsevier: Amsterdam, 1992), p. 171, cited in Heike Spieker, "Humanitarian Assistance, Access in Armed Conflict and Occupation," in: Rüdiger Wolfrum (ed.), The Max Planck Encyclopedia of Public International Law, (OUP: Oxford, 2008, online edition, www.mpepil.com), para. 29.

83 UN SC Res. 1973 (2011), para. 3.

84 MSF, "MSF Team in Libya Trying to Reach Areas Affected by Violence," 24 February 2011, http://www.doctorswithoutborders.org/news/article.cfm?id=5053\&cat=field-news.

85 MSF, "Libya: Aid Access to Violence-Affected Areas Blocked," 2 March 2011, http://www.doctorswithoutborders.org/press/release.cfm?id=5076\&cat=press-release; MSF, "Libya: MSF Seeking More Ways to Assist Wounded," 8 March 2011, http://www.doctorswithoutborders.org/news/article.cfm?id=5085\&cat=field-news.

${ }^{86}$ Cf. ICRC, "International Humanitarian Law and the Challenges of Contemporary Armed Conflicts" (October 2011), http://www.icrc.org/eng/assets/files/red-cross-crescent-movement/31st-international-conference/31-intconference-ihl-challenges-report-11-5-1-2-en.pdf, p. 24 (observing that security-related constraints are among the main reasons limiting humanitarian access in practice).

${ }^{87}$ Williams and Bellamy, "Principles, Politics and Prudence", p. 278.
} 
reaching the wounded in the places of hostilities. ${ }^{88}$ These reports would indicate a violation of the rules on humanitarian access by the government at the time.

Following the international intervention in March 2011, the Libyan government agreed to negotiate to allow foreign aid inside the country. The crowning achievement of this effort was an agreement signed with the UN on 17 April, according to which Libya allowed international humanitarian access to all areas affected by the conflict. ${ }^{89}$ In the official government proclamations, Libya insisted that it was acting consistently with this agreement. ${ }^{90}$

Second, between the months of March and May, some of the most protracted fighting of the conflict unfolded in the city of Misrata situated on the Mediterranean coast in north-western Libya. ${ }^{91}$ Gaddafi's forces placed the city under siege and very early on, a Libyan army general reportedly gave an order not to allow any 'supply cars, fuel and other services to enter the city of Misrata from all gates and checkpoints'. ${ }^{92}$ It appears, however, that both sides of the conflict contributed to inflicting hardship on the inhabitants of Misrata. For the most part of the siege, the rebels controlled the access to the city by sea and the government forces were in control of the land access. ${ }^{93}$ The United Nations humanitarian chief Valerie Amos complained in April that 'the opposition' was preventing humanitarian access via the city's port. ${ }^{94}$ The complaints against the government's conduct during the siege were even more severe. Gaddafi's forces continued to block access to Misrata by road despite the humanitarian agreement with the UN, thus occasioning serious shortages among the civilian population. ${ }^{95}$ After the rebels allowed the usage of the Misrata port for humanitarian purposes, it became 'the only lifeline for humanitarian aid and an evacuation route for the war-wounded'. ${ }^{96}$ This did not, however, stop the government forces from attempting to destroy the port by numerous attacks ${ }^{97}$ and from launching land-mines on it. ${ }^{98}$ In summary, these actions prevented humanitarian aid from accessing war-torn Misrata and delayed the evacuation of the victims of the war.

There is little to add from the legal standpoint. Siege warfare is not prohibited as such in NIACs. ${ }^{99}$ It must not, however, bring about the starvation of civilians. ${ }^{100}$ The means used by the government, and to a lesser extent, the rebel forces as well as the indications of intent found in

88 MSF, "Libya: Urgent Priority Must Be Given to Doctors and Medical Materials," 25 February 2011, http://www.doctorswithoutborders.org/press/release.cfm?id=5063\&cat=press-release; Al Jazeera, “Gaddafi loyalists launch $\quad 11 \quad$ March http://www.aljazeera.com/news/africa/2011/03/201131041228856242.html.

${ }^{89}$ UN Doc. S/PV.6527 (3 May 2011), p. 3; see also BBC, "Libyan Government Promises Aid Workers Access, UN Says," 19 April 2011, http://www.bbc.co.uk/news/world-africa-13125616.

90 See, eg, UN Doc. S/PV.6541 (31 May 2011), p. 4.

${ }^{91}$ International Commission of Inquiry March 2012 Report, para. 73.

92 The Guardian, "Gaddafi Files Show Evidence of Murderous Intent," 18 June 2011, http://www.guardian.co.uk/world/2011/jun/18/gaddafi-misrata-war-crime-documents.

93 See, eg, The Guardian, "Libya Rebels Ask Nato for Help as Gaddafi Forces Bombard Misrata," 2 May 2011, http://www.guardian.co.uk/world/2011/may/02/libya-rebels-gaddafi-bombard-misrata.

94 The World, "The Risk for Aid Workers in Libya," 19 April 2011, http://www.theworld.org/2011/04/the-riskfor-aid-workers-in-libya/.

95 Amnesty International, “The Battle for Libya” (2011), p. 34; International Commission of Inquiry March 2012 Report, para. 554; Amnesty International, "Misratah - Under Siege and Under Fire” (2011), p. 6.

${ }^{6}$ International Commission of Inquiry March 2012 Report, para. 87; see also Amnesty International, "The Battle for Libya" (2011), p. 8.

${ }^{97}$ Amnesty International, “The Battle for Libya” (2011), p. 34; International Commission of Inquiry March 2012 Report, para. 73.

98 The New York Times, "Land Mines Descend on Misurata’s Port, Endangering Libyan City's Supply Route," 6 May 2011, http://www.nytimes.com/2011/05/07/world/africa/07libya.html?_r=0; International Commission of Inquiry March 2012 Report, para. 73; Amnesty International, “The Battle for Libya” (2011), p. 54.

${ }^{99}$ Cf. APs Commentary, p. 1457, paras. 4796-7.

100 AP II, Art. 14. 
the proclamations by the government, indicate that violations of the relevant rules of IHL had been committed in relation to Misrata.

Finally, we turn to the closing phase of the conflict in September and October, when following the fall of Tripoli, the remnants of Gaddafi's forces retreated to the last remaining loyalist outposts in Sirte and Bani Walid. Tables have turned and now the insurgents encircled these cities and mounted military pressure against them. As the siege began, the rebels threatened to cut-off essential supplies and did not hide their intention to starve the inhabitants to induce surrender. ${ }^{101}$ They reportedly prevented humanitarian aid workers from entering Sirte, exacerbating the existing shortages of basic necessities, medical supplies, electricity and water. ${ }^{102}$ At the same time, civilians were not allowed to leave the city and were subjected to prolonged controls at checkpoints by the NTC forces. ${ }^{103}$ Again, the situation was further aggravated by the other side: Gaddafi loyalists reportedly robbed food stores, leaving unaligned civilians with even fewer resources available. ${ }^{104}$ It took at least two weeks until the ICRC finally managed to negotiate access to Sirte and provide the first humanitarian aid to the inhabitants. ${ }^{105}$ All of this conduct, if factually true, constituted a violation of humanitarian access obligations.

What impact does the described pattern of conduct have on the principles of neutrality and impartiality of humanitarian action? Both parties nominally acknowledged the application of the rules on humanitarian access to the situation in Libya. ${ }^{106}$ By preventing the outside aid from reaching the civilians whose allegiance lay with the enemy or even those who only happened to find themselves in the territory controlled by the other side, the conflict parties certainly hindered fully impartial disbursement of aid. They did not, however, attempt to justify their conduct by any legal reasons; in fact, when justification was given, it was claimed that access was prevented due to 'security reasons'. ${ }^{107}$ The attempts to deny the existence of alleged violations only strengthen the principles which would thus have been violated. ${ }^{108}$ The deplorable events described in this section thus deserve to be referred to post-conflict accountability processes, ${ }^{109}$ but they have not undermined the analysed principles.

101 Fox News, "U.N. Warns Libya Is Short of Water, Fuel, Medicine," 2 September 2011, http://www.foxnews.com/world/2011/09/02/un-warns-libya-is-short-water-fuel-medicine/; The Telegraph, "Libya Crisis: Rebel Leaders Hoping to Starve Gaddafi Stronghold of Sirte into Submission," 28 August 2011, http://www.telegraph.co.uk/news/worldnews/africaandindianocean/libya/8728752/Libya-crisis-Rebel-leadershoping-to-starve-Gaddafi-stronghold-of-Sirte-into-submission.html.

102 International Commission of Inquiry March 2012 Report, para. 576; CNN, "United Nations Team Arrives in Libya," 2 September 2011, http://articles.cnn.com/2011-09-02/world/libya.war_1_water-shortages-bottled-watermoammar-gadhafi/3?_s=PM:WORLD; Reuters, "UN Says Cannot Get Supplies into Libya Stronghold," 26 September 2011, http://www.reuters.com/article/2011/09/26/libya-aid-idAFL5E7KQ2MM20110926>.

103 Maximilian Forte, Slouching Towards Sirte: NATO's W ar on Libya and Africa (Montreal: Baraka, 2012), pp. 95-7.

104 CNN, "NTC Claims Humanitarian Disaster in Gadhafi Stronghold," 19 September 2011, http://articles.cnn.com/2011-09-19/africa/world_africa_libya-war_1_gadhafi-forces-gadhafi-loyalists-moammargadhafi?_s=PM:AFRICA.

105 Amnesty International, "Warring Libyan Forces Must Allow Humanitarian Aid Reach Sirte,” 3 October 2011, http://www.amnesty.org/en/news-and-updates/warring-libyan-forces-must-allow-humanitarian-aid-reach-sirte2011-10-03.

106 See note 89 above (re Libyan government's humanitarian agreement with the UN); NTC, Press Statement (August 2011), http://ntclibyaus.files.wordpress.com/2011/08/ntc-ps-laws2.pdf (re NTC's acknowledgement of applicability of Common Article 3 and AP II to the situation in Libya).

107 See, eg, Reuters, "UN Says Cannot Get Supplies into Libya Stronghold," 26 September 2011, http://www.reuters.com/article/2011/09/26/libya-aid-idAFL5E7KQ2MM20110926.

108 Cf. Nicaragua, para. 186 (a State that resorts to justifications contained within a rule, which it is alleged to have violated, confirms rather than weakens the rule in question).

109 Denial of humanitarian assistance may constitute one of several possible international crimes. See generally Christa Rottensteiner, “The Denial of Humanitarian Assistance as a Crime under International Law," IRRC 835 (1999), pp. 555-582. 


\section{b. Multi-purpose actors}

The second type of humanitarian agents acting inside Libya were the multi-purpose actors like States and intergovernmental organisations including the UN, NATO, and the EU. The label 'multi-purpose' denotes the fact that these actors were pursuing their political and military goals simultaneously with their humanitarian aims. In other recent conflicts, most notably Iraq and Afghanistan, principles of impartiality and neutrality were seen as most endangered precisely by the 'blurring of lines' between the variously defined tasks of such multi-purpose actors. ${ }^{110}$ In this section, we focus on two main issues facing these actors: the question of overstepping the mandate given to the implementing States by the Security Council in Resolution 1973 and the question of separation of humanitarian and other activities in the conduct of intergovernmental organisations.

\section{Security Council mandate}

Did the execution of the mandate given to the States by the Security Council in March 2011 overstep its legal boundaries? It is uncontested that the international coalition's use of military force targeted exclusively forces belonging to one side of the conflict. We can thus hardly speak of 'neutrality' with respect to the military action undertaken by the allied States. However, since the intervention in Libya was conducted for humanitarian purposes, it would ordinarily have had to follow the principle of neutrality and avoid assisting one or the other side's military efforts. The interpretation of the legal mandate in Resolution 1973 thus acquires critical importance. It has long been understood that obligations imposed by the Security Council acting under Chapter VII of the UN Charter trump any conflicting international law obligations. ${ }^{111}$ Therefore, the authorisation of the Security Council would override any commitment to the principle of neutrality the intervening States would otherwise have under international law, provided, of course, that it would allow them to associate with a party to the conflict.

It would be incorrect to describe the resolution as entirely neutral vis-à-vis the conflict parties. It expressly condemned acts of violence perpetrated by the government forces and remained silent with respect to the conduct of the insurgents. ${ }^{112}$ It strengthened and extended the asset freeze of persons closely associated with the regime imposed by the preceding Resolution $1970 .{ }^{113}$ It further extended the travel ban, again imposed by Resolution 1970, to additional representatives of the regime. ${ }^{114}$ None of these restrictions were applicable to persons associated with the other conflict party.

Nevertheless, the resolution did not authorise the use of force to assist the insurgents in their armed struggle or even to remove Gaddafi's regime altogether. ${ }^{115}$ An express authorisation of this sort was given by the Council during the Haiti crisis in the early 1990s when it authorised Member States 'to form a multinational force' and 'to use all necessary means to facilitate the departure from Haiti of the military leadership [and] the prompt return of the legitimately elected President ${ }^{\text {, }}{ }^{116}$ In contrast, Resolution 1973 was much more restrictive in its terms:

\footnotetext{
110 See sources cited in notes 18-20 above.

${ }^{111}$ Lockerbie case, p. 15, para. 39.

112 Cf. UN SC Res. 1973 (2011), preambular para. 6.

113 UN SC Res. 1973 (2011), paras. 19 and 22, and Annex I; see also UN SC Res. 1970 (2011), para. 17 and Annex II.

114 UN SC Res. 1973 (2011), para. 22 and Annex I; see also UN SC Res. 1970 (2011), para. 15 and Annex I.

115 See section II.B above for the assessment of the qualitative nature of aid permitted by Resolution 1973.

116 UN SC Res. 940 (1994), para. 4.
} 
[Security Council a]uthorizes Member States that have notified the SecretaryGeneral, acting nationally or through regional organizations or arrangements, and acting in cooperation with the Secretary-General, to take all necessary measures, notwithstanding paragraph 9 of resolution 1970 (2011), to protect civilians and civilian populated areas under threat of attack in the Libyan Arab Jamabiriya, including Benghari, while excluding a foreign occupation force of any form on any part of Libyan territory[.] ${ }^{117}$

The mandate to protect civilians, without siding with one of the conflict parties, is in line with most of the recent practice of the Security Council. ${ }^{118}$ Still, several abstaining members expressed their concern that the resolution left unclear the extent to which enforcement measures could be used permissibly under the resolution. ${ }^{119}$ For the same reasons as above, it is submitted here that any ambiguity left by the wording of a Council resolution should be construed restrictively against a broad use of force, in order to allow only the minimum force necessary to achieve the goals stated in the resolution. ${ }^{120}$

In the first weeks of the intervention, it appeared that this approach was also adopted by the intervening States. In early April, NATO warned the rebels not to target civilians and threatened them that such attacks would be followed with retaliatory strikes. ${ }^{121}$ In the same period, the rebels reported feeling 'disappointed' by NATO for not heeding their requests to strike against particular government targets. ${ }^{122}$ In the early phases of the conflict it thus appeared plausible that as soon as the situation would be stabilised and the civilians put out of immediate danger, outside use of force would cease.

Although there had been some earlier calls for Gaddafi to step down, ${ }^{123}$ the position of the intervening States began to shift following the publication in mid-April of an influential open letter signed by the American and French presidents and the British prime minister. ${ }^{124}$ In it, they pledged to maintain military pressure on Gaddafi's government until a transition process would take place in Libya, emphasising expressly that in order for that transition to succeed, 'Gaddafi must go, and go for good'. ${ }^{125}$ The informal Libya contact group-which counted among its members all of the intervening States-appropriated this position soon after and continued to openly call for the end of Gaddafi's regime. ${ }^{126}$

These proclamations were accompanied by corresponding action on the ground. Abandoning their initial hesitation, international forces provided the insurgents with unyielding

\footnotetext{
117 UN SC Res. 1973 (2011), para. 4 (emphasis added).

118 See, eg, UN SC Res. 1270 (1999), para. 14 and UN SC Res. 1289 (2000), para. 10 (regarding the situation in Sierra Leone); UN SC Res. 1706 (2006), para. 12 (regarding the situation in Darfur); UN SC Res. 1861 (2009), para. 7 (regarding the situation in Chad and the Central African Republic); but see UN SC Res. 1975 (2011), paras. 3 and 6 (authorising the use of force to protect civilians in Côte d'Ivoire while urging President Laurent Gbagbo to step aside).

119 See, especially, UN Doc. S/PV.6498 (17 March 2011), p. 6 (statements of the representatives of India and Brazil), p. 8 (statement of the representative of Russia), p. 10 (statement of the representative of China).

120 See text to notes 54-55 above.

121 The New York Times, "NATO Warns Rebels Against Attacking Civilians," 1 April 2011, http://www.nytimes.com/2011/04/01/world/africa/01 civilians.html?_r=1\&src=twrhp\&pagewanted=all.

$122 \mathrm{Al}$ Jazeera, “Libyan rebels 'disappointed' by NATO," 6 April 2011, http://www.aljazeera.com/news/africa/2011/04/201145191641347449.html.

${ }^{123}$ See, eg, European Council, EUCO 7/1/11 REV 1, 11 March 2011, para. 7 ('Colonel Kadhafi must relinquish power immediately.').

${ }^{124}$ Barack Obama, David Cameron, and Nicolas Sarkozy, "Libya's Pathway to Peace," The New York Times, 14 April 2011, http://www.nytimes.com/2011/04/15/opinion/15iht-edlibya15.html.

125 Ibid.

126 Pommier, "The Use of Force", p. 1068.
} 
aerial support in their struggle to defeat Gaddafi. According to some reports, a joint operations centre was established in Benghazi with the aim to 'coordinate and make more effective the processing of military and tactical information back to NATO' ${ }^{127}$ During the battle of Tripoli, NATO destroyed the building of the Libyan state television, poignantly described by the New York Times as 'a purely political tool that only directly threatened civilians perhaps by boring them'. ${ }^{28}$ Finally, the air strikes continued even after the fall of the capital and after the loyalists retreated into the cities of Sirte and Bani Walid, at a time when any claims of Gaddafi posing a threat to the civilians became very difficult to justify.

One of the States that voted in favour of Resolution 1973, South Africa made a strong proclamation in June 2011 emphasising that its intention at the time of the vote had been 'to ensure the protection of civilians as well as unhindered access to humanitarian aid' but 'never regime change. ${ }^{129}$ Similar complaints that the mandate had been overstepped came from States that had initially abstained. ${ }^{130}$ Although according to Russia, NATO was requested to submit a report on its compliance with the mandate, this had not been done. ${ }^{131}$ It thus appears fairly safe to conclude that the Security Council mandate had not been respected during the Libyan conflict ${ }^{132}$ and that instead, a coup d'état humanitaire took place there. ${ }^{133}$

Correspondingly, the non-neutral implementation of the mandate contributed to the weakening of the principle of neutrality of humanitarian action. In addition, the prospects of Security Council-authorised humanitarian action in similar situations in the future have probably diminished because countries known for their more conservative approach to UN-mandated use of force such as China and Russia have grown even more wary of the risk that the agreed mandate would be stretched beyond expectation. ${ }^{134}$

\section{Blurring the lines}

Traditionally, there was a clear dividing line between the categories of actors who were involved in a conflict and those responding to it. This division safeguarded the neutrality and impartiality of humanitarian aid as the agents of response did not share the political motivations of the

127 Bruno Waterfield, “Libya: British Military Advisers Set up 'Joint Operations Centre' in Benghazi," The Telegraph, 18 May 2011, www.telegraph.co.uk/news/worldnews/africaandindianocean/libya/8521977/Libya-British-militaryadvisers-set-up-joint-operations-centre-in-Benghazi.html. See text to notes 32-33 above for the relevance of this centre's existence for conflict qualification.

128 The New York Times, "NATO Strikes at Libyan State TV," 30 July 2011, http://www.nytimes.com/2011/07/31/world/africa/31tripoli.html.

129 UN Doc. S/PV.6566 (27 June 2011), p. 4

130 See, eg, UN Doc. S/PV.6531 (10 May 2011), p. 20 (statement of the Chinese representative); UN Doc. S/PV.6620 (16 September 2011), p. 2 (statement of the Russian representative').

131 Statement of the Russian representative to the Security Council at a press conference on 2 December 2011, http://www.unmultimedia.org/tv/webcast/2011/12/press-conference-ambassador-vitaly-churkin-president-of-thesecurity-council.html.

${ }^{132}$ Contra Mehrdad Payandeh, "The United Nations, Military Intervention, and Regime Change in Libya," Virginia Journal of International Law 52 (2012), pp. 387-91 (arguing that regime change might have been a legitimate means to pursue the goal of protection of civilians established by the Security Council).

133 The term is Rony Brauman's. See Pierre Haski, "Rony Brauman: 'De quel droit demander à Kadhafi de partir?'," Rue89, 15 April 2011, http://www.rue89.com/2011/04/15/rony-brauman-de-quel-droit-demander-a-kadhafi-departir-200152.

134 See also Letter from the Permanent Representative of the Russian Federation to the United Nations addressed to the Secretary-General, UN Doc. A/66/594-S/2011/758 (7 December 2011) (calling on behalf of the BRICS countries for strict implementation of Security Council decisions and noting that these countries considered it inadmissible to forcibly impose political solutions on the States in the Middle East and North Africa); Letter from the Permanent Representative of Brazil to the United Nations addressed to the Secretary-General, UN Doc. A/66/551-S/2011/701 (9 November 2011), para. 10 (warning against the misuse of the R2P concept for 'purposes other than protecting civilians, such as regime change'). 
agents involved in the conflict. As intergovernmental organisations gradually took on both of these roles in modern conflicts, they came under fire for blurring the traditional lines. In this subsection, we look at the extent to which three key intergovernmental players-NATO, the $\mathrm{UN}$, and the EU-succeeded in maintaining the separation of their various roles in Libya.

Leaving aside the question of the use of force discussed above, as for humanitarian aid narrowly understood, NATO was a relatively straightforward case. Consistent with its predominantly military character, it portrayed its role as enabling of humanitarian assistance, but not as direct provision of aid to the conflict parties. Even before the intervention, NATO announced that it was moving additional ships into the region to support humanitarian assistance efforts. ${ }^{135}$ NATO's own statistics speak of over 2,500 air, ground, and maritime movements of humanitarian character being 'de-conflicted' (or provided with safe passage) by the Alliance. ${ }^{136}$ Although arguments have been made to the effect that NATO's role was not limited to maritime and aerial operations under the Security Council mandate, NATO never brought ground troops into Libya to protect humanitarian convoys on land. ${ }^{137}$ Notably, such deployment was also opposed by the Libyan government, even after it concluded the April humanitarian agreement allowing unimpeded access for humanitarian aid into Libya. ${ }^{138}$

There have been some indications that NATO prioritised on some occasions its military objectives over the humanitarian needs of the civilian population. The most prominent of these was the case of the 'left-to-die boat' with 72 people on board who had been drifting at sea for over two weeks in March and April without fuel, food, or drinking water, before washing up on the Libyan shores with only nine survivors. The harrowing fate of the escapees attracted media attention and resulted in an extensive report by the Parliamentary Assembly of the Council of Europe. ${ }^{139}$ The report shows that although the drifting rubber boat had been in the vicinity of at least two NATO military vessels, the Alliance failed to react to the distress calls and left the passengers to their own devices. ${ }^{140}$ According to the report, this failure was a consequence of the general lack of preparations for the foreseeable exodus of people fleeing the conflict. ${ }^{141}$ If the factual assessment in the report is correct, NATO's conduct would amount to a violation of its law of the sea obligations to search and rescue persons in distress. ${ }^{142}$ However, it appears to confirm that NATO did not see its role as a direct humanitarian actor in the Libyan conflict and consequently did not significantly contribute to the blurring of the lines analysed in this subsection.

The UN found itself in a more precarious situation. It had to reconcile its role as, on the one hand, the organisation providing the mandate to use force inside Libya, including against the government forces and installations, and, on the other hand, the organisation tasked to provide humanitarian relief to the conflict victims on both sides. At a meeting of relief agencies in Cairo in June 2011, Panos Moumtzis, the UN humanitarian coordinator for Libya, acknowledged this

\footnotetext{
135 Williams and Bellamy, "Principles, Politics and Prudence", pp. 277-8; see further NATO, "NATO Ready to Support International Efforts on Libya," 10 March 2011, http://www.nato.int/cps/en/natolive/news_71446.htm. 136 NATO, “Operation UNIFIED PROTECTOR Final Mission Stats," 2 November 2011, http://www.nato.int/nato_static/assets/pdf/pdf_2011_11/20111108_111107-factsheet_up_factsfigures_en.pdf.

137 See, eg, Payandeh, “The United Nations”, pp. 385-6; Michael N. Schmitt, "Wings over Libya: The No-Fly Zone in Legal Perspective," Yale Journal of International Law Online 36 (2011), p. 46 n 6.

138 Mumbai Mirror, "Libya 'No' to Foreign Troops with UN Aid," 20 April 2011, http://www.mumbaimirror.com/article/4/201104202011042002165198234eb6890/Libya-

$\% \mathrm{E} 2 \% 80 \% 98 \mathrm{no} \% \mathrm{E} 2 \% 80 \% 99$-to-foreign-troops-with-UN-aid.html?pageno=17.

139 CoE, "Lives Lost in the Mediterranean Sea: Who is Responsible?," 29 March 2012, http://assembly.coe.int/CommitteeDocs/2012/20120329_mig_RPT.EN.pdf> (hereinafter 'CoE report').

${ }^{140} \mathrm{CoE}$ report, para. 8.

${ }^{141}$ CoE report, para. 11.

142 UNCLOS, Art. 98(1).
} 
challenge and noted that 'the humanitarian team carries the same UN flag as the Security Council'. ${ }^{143}$

Nevertheless, the UN confirmed on several occasions its commitment to the principles of impartiality and neutrality of humanitarian action with respect to the Libyan conflict. ${ }^{144} \mathrm{UN}$ representatives maintained constant contact with both sides ${ }^{145}$ and succeeded in convincing the conflict parties to permit access for humanitarian agencies to all areas of Libya. ${ }^{146}$

Conversely, the perception of the UN as a strictly neutral humanitarian actor was put to doubt by its simultaneous preparation for a post-Gaddafi era. In April 2011, the UN established the position of Special Adviser to the Secretary-General on Post-Conflict Planning for Libya and appointed Ian Martin to fill it. He then seamlessly became the head of the United Nations Support Mission for Libya (UNSMIL) when it was created by the Security Council in September 2011 at the behest of the new Libyan authorities. ${ }^{147}$ Through Mr Martin and later UNSMIL, the UN focused on development goals and political stabilisation, thus going beyond strict neutrality, considering that such aims inevitably favoured the victorious side in the civil war.

This degree of two-facedness likely contributed towards some of the domestic backlash against the organisation. In a notable incident that followed the death of the son of Muammar Gaddafi, Saif al-Arab, in a NATO bombing in April 2011, the UN office in Tripoli was ransacked by angry local mobs, leading to the temporary withdrawal of all international staff. ${ }^{148}$ We may thus conclude that the UN struggled to maintain a clear-cut and understandable separation of its strictly humanitarian and other broader roles during the Libyan conflict.

Finally, the activity of the EU can be given somewhat better marks from the perspective of role separation. Since the adoption of the Lisbon Treaty, the EU benefits from a clear legal basis outlining the principles underlying its humanitarian action and separating the humanitarian objectives from other foreign policy goals of the Union. ${ }^{149}$ It has thus introduced an explicit Union competence in the field of humanitarian aid relating to the provision of 'ad hoc assistance and relief and protection for people in third countries who are victims of natural or man-made disasters'. ${ }^{150}$ Such operations by the EU must 'be conducted in compliance with the principles of international law and with the principles of impartiality, neutrality and non-discrimination'. ${ }^{151}$

In Libya, the need for this separation was acutely felt. The EU participated through its foreign policy arm, the External Action Service, in the anti-Gaddafi contact group and it consistently maintained an anti-Gaddafi position in the public proclamations of its representatives. ${ }^{152}$ These actions clearly overstep the boundaries of the principle of neutrality.

143 Humanitarian Partnership Forum 'Sharaka', Final Report, 6 June 2011, http://www.humanitarianforum.org/data/files/29_final_report_humanitarian_partnership_forum_29_june_2011.p df, p. 15.

${ }^{144}$ UN, "Strengthening of the Coordination of Emergency Humanitarian Assistance of the United Nations," 16 May 2011, UN Doc. A/66/81-E/2011/117, http://www.un.org/en/ecosoc/julyhls/pdf11/sg_report_on_strengthening_coordination_a-66-81_e-2011-117.pdf, paras. 71,74 , and 80 (a).

145 See, eg, UN Doc. S/PV.6509, p. 4.

146 See text to note 89 above.

147 UN SC Res. 2009 (2011).

148 Al Jazeera, “UN Staff Leave Tripoli after Mob Attack," 2 May 2011, http://www.aljazeera.com/news/africa/2011/05/201151225143642809.html.

${ }^{149}$ Before the Lisbon Treaty entered into force, humanitarian aid was based on Article 179 of the EC Treaty, which dealt with development policy.

150 TFEU, Art. 214(1).

151 TFEU, Art. 214(2).

152 See, eg, European Council, EUCO 7/1/11 REV 1, 11 March 2011, para. 7; Statement by Catherine Ashton, 22 August 2011, http://reliefweb.int/sites/reliefweb.int/files/resources/F_R_253.pdf. 
However, EU's humanitarian arm, the Directorate-General for Humanitarian Aid and Civil Protection of the European Commission (known under the acronym of its predecessor as $\mathrm{ECHO}^{153}$ ), maintained that it operated independently from the External Action Service and that it was 'blind to political, religious, or any other considerations'. ${ }^{154}$ ECHO disbursed assistance totalling over $€ 80 \mathrm{~m}$ in the form of emergency aid and repatriation operations. ${ }^{155}$ It did so mainly through partner organisations whose dedication to neutrality and impartiality has long been established, including the ICRC, the IOM, and the UNHCR. ${ }^{156}$ The ICRC President Jakob Kellenberger himself accepted that the funding priorities of ECHO were 'one of the best proofs' of its attachment to the principles of humanitarian action. ${ }^{157}$ Legal and operational separation of humanitarian aid from other foreign policy priorities thus seemed to have dispelled concerns over impartiality and neutrality of EU humanitarian action in the Libyan conflict. ${ }^{158}$

\section{Conclusion}

There is no doubt that humanitarian principles of impartiality and neutrality carry great importance even in the aftermath of the Libyan conflict. Both sides of the conflict certainly bear their share of responsibility for preventing humanitarian access to the victims on the ground. However, without the general understanding that humanitarian agents do not, or at least should not, have any other loyalty except to the persons in need, even the limited observance of the law would become illusory. We must therefore learn from the lessons of Libya to protect these principles for the future.

For the States that are not directly affected by the conflict as it is not taking place in their territory, these lessons may be drawn on two levels. First, the aid they decide to provide to a conflict-stricken country should not quantitatively favour one of the conflict sides nor should it exceed what can qualitatively be considered legitimate humanitarian aid. Second, if there is a Security Council mandate allowing outside States to intervene to protect the civilians affected by the conflict, its implementation should be based on a restrictive interpretation of its terms. To do otherwise means to risk that the Council will be unwilling to permit similar action in future crises, as has been demonstrated by the unfortunate Syrian situation so soon after Libya.

It is a sad role of the academic to point to the violations committed by the conflict parties while being fully aware that future conflicts will hardly be much different. However, even this cloud has a silver lining. Both conflict parties in Libya have formally acknowledged their acceptance of IHL obligations relating to humanitarian access and neither of them has attempted to claim that these duties would be unfair or unfeasible for reasons of military necessity.

${ }^{153}$ ECHO stood for 'European Community Humanitarian Office' and it was established in 1992 by Regulation (CE) No. 1257/96. It transformed into a Directorate-General in 2004.

154 ICRC, "Discussion: What are the Future Challenges for Humanitarian Action?," IRRC 884 (2011), p. 908 (statement by Commissioner Kristalina Georgieva).

155 ECHO, "Timeline of the Libyan Crisis," $17 \quad$ February 2012, http://ec.europa.eu/echo/media/photos/picture_stories/libya06_en.htm.

156 ECHO, "Libyan Crisis: Humanitarian Partners," 18 August 2011, http:/ / ec.europa.eu/echo/files/aid/countries/libya_partners_funding_en.pdf.

157 ICRC, "Discussion: What are the Future Challenges for Humanitarian Action?," IRRC 884 (2011), p. 909 (statement by ICRC president Jakob Kellenberger).

158 This conclusion might have had to be modified if the EU's offer to deploy a military force to protect humanitarian agencies in Libya had been accepted and activated by the UN. EU decided to create the European Union Force-Libya (EUFOR Libya) in April 2011; its deployment had been, however, contingent on a request being made by the UN OCHA. Since the UN Under-Secretary-General for Humanitarian Affairs and Emergency Relief Coordinator, Valerie Amos, considered this military operation unnecessary and useful only as a last resort, the request was never made. Had the EUFOR been deployed, its military nature and its support of humanitarian operations would very likely have further contributed to the blurring of lines described in this section. See further Pommier, "The Use of Force”, pp. 1069-70. 
Similarly, they have not claimed a right only to allow aid to 'their own' civilian population; on the contrary, if the alleged violations were reacted upon in any way by the belligerents, it was to deny that anything like that had happened. The principles and the rules relating to humanitarian action thus survive intact and even reaffirmed by this conduct as it is rather their implementation that was found wanting.

Finally, some good practice can be identified in the conduct of the international organisations involved in the Libyan conflict. 'Dunantist' agencies such as the ICRC and MSF have again shown that it is principally possible to act in an impartial and neutral way, although their efforts were certainly hampered in many ways by other actors on the ground. The EU has served as a positive example of a multi-purpose actor capable of satisfactory legal and operational separation of its humanitarian and non-humanitarian roles. Conversely, NATO and UN involvement in the conflict rather put the principles of impartiality and neutrality under further strain on account of the far-reaching interpretation of the Security Council mandate by NATO and the UN's blurring of lines between its various roles.

Humanitarian principles of impartiality and neutrality have certainly not died in Libya. Commitment to them as to fundamental principles of humanitarian action has been confirmed by virtually all key actors in that conflict. Likewise, the conduct of many of them has indeed been guided by these principles. At the same time, it is undeniable that the Libyan events have put these principles under considerable strain. It was the aim of this chapter to highlight the most notable of those instances and thus contribute in a modest way to the strengthening of these principles in the future. 